\title{
PROSPEK USAHA PENGGEMUKAN SAPI BRAHMA DI KABUPATEN OKU TIMUR
}

\author{
(Parmaji)
}

\begin{abstract}
The purpose of this study is to: (1) To know the cost of production, acceptance and income of brahman cattle fattening in Eastern OKU, (2) To know the added value of brahman cattle fattening in East OKU, (3) Feasibility of brahman cattle fattening business in East OKU Regency. The research was conducted in OKU Timur Regency, with purposive determination of the research location with the consideration that there are still a few businessmen of cattle fattening who choose to fatten brahman cow, whereas the brahman cattle fattening in OKU Timur Regency has good prospect. This is because demand brahman cows from year to year continues to increase, in addition to the brushed cattle brewing process is quite easy and in a relatively long time has gained profits. This research has been conducted in March 2015 until May 2015 on the brahman cattle fattening that already existed in East OKU Regency. This study found that the average cost of production for brahman cattle fattening business is Rp. 79.438.224, - I PP, with a flat fee of Rp. 3,588,335, - / PP, and variable cost of Rp. 75.849.889, - / PP. Receipt is Rp. 123.333.333, - / PP then obtained revenue of $R p .43 .895 .109$, - / PP (Rp 7,315,852, - / Month). The added value of brahman cattle fattening business in Kabupaten OKU Timur is Rp. 59.305.278, - / tail (Rp 118.610.555, - / PP or Rp 19.768.426, - / Month). Brahman cattle fattening business in East OKU district can be said to be profitable and feasible to do. This is because the brackish cattle fattening business obtained NPV value at the bank interest rate of 18\% (Rp 85.691.855, -) with the value of Net B / C of 1.89 and the value of IRR 32.16\% which means feasible or effort can be done Because advantageous. So, brahman cattle fattening in Regency OKU East have good prospect to be developed.
\end{abstract}

Key Words : Value-added, Cow fattening, Business Feasibility Study.

\section{PENDAHULUAN}

\section{A. Latar Belakang}

Usaha penggemukan sapi di Indonesia adalah salah satu usaha yang cukup berpotensi untuk dikembangkan karena dapat meningkatkan perekonomian. Selain itu, usaha penggemukan sapi relatif mudah, karena tidak tergantung pada ketersedian lahan, tenaga kerja yang berkualitas tinggi, serta membuka lapangan pekerjaan. Akan tetapi, modal yang dibutuhkan untuk memulai usaha penggemukan sapi cukup besar. Sedangkan, pada umumnya usaha penggemukan sapi diharapkan dapat menghasilkan produk daging sapi yang berkualitas (Hardjosubroto, 2004).

Konsumsi daging di Indonesia terus mengalami peningkatan, akan tetapi peningkatan tersebut belum diimbangi dengan penambahan produksi yang memadai. Salah satu penyebabnya adalah lambatnya peningkatan populasi penggemukan sapi, sehingga sumbangan terhadap produksi daging nasional rendah. Tingkat konsumsi daging pada tahun 2012 di Indonesia sebesar 2,72 $\mathrm{kg} /$ perkapita/tahun, sehingga kebutuhan daging dalam negeri mencapai 654.400 ton dengan rata-rata tingkat pertumbuhan konsumsi 1,49\%/tahun (Bade, 2002).
Kebutuhan daging sapi di Indonesia pada saat ini dipenuhi dari tiga sumber yaitu ternak sapi lokal, hasil penggemukan sapi ekspor impor, dan impor daging dari luar negeri. Daging sapi merupakan salah satu sumber protein hewani yang banyak dibutuhkan konsumen, akan tetapi sampai pada saat ini Indonesia belum mampu memenuhi kebutuhan konsumen sehingga sebagian masih harus diimpor. Kondisi tersebut memberikan peluang untuk pengembangan usaha penggemukan sapi, dengan harapan dapat menghasilkan daging sapi yang banyak dan berkualitas baik sehingga memiliki harga yang tinggi di pasaran (Gunawan, 2008).

Pemerintah dalam memenuhi kebutuhan daging nasional melakukan beberapa cara antara lain impor daging sapi dan sapi bakalan untuk digemukan. Impor daging biasanya dalam bentuk beku, dan impor bakalan sapi yang untuk digemukan biasanya dilakukan karena usaha pembibitan umumnya di daerah dataran rendah dengan ketersedian pakan relatif kurang. Sedangkan, untuk penggemukan sapi banyak terdapat di daerah dataran tinggi dengan ketersedian pakan relatif cukup. Usaha pembibitan relatif tidak memerlukan banyak pakan karena tujuan utamanya adalah untuk 
menghasilkan pedet, sedangkan untuk usaha penggemukan sapi memerlukan pakan yang lebih banyak karena tujuan utamanya untuk menghasilkan daging (Rivai, 2009).

Beberapa investasi yang berhubungan dengan peternakan sapi yang biasa dilakukan adalah penggemukan sapi dan pembibitan sapi potong. Akan tetapi, pengusaha kebanyakan lebih memilih usaha penggemukan sapi karena dapat dikatakan sebagai investasi yang lebih menguntungkan dan relatif aman. Hal tersebut dikarenakan selain sapi merupakan hewan yang tangguh dan tidak mudah terkena penyakit, serta pertumbuhan badan yang cepat. Harga sapi dipasaran juga relatif stabil dan hasil penggemukan sapi mudah diserap pasar (Aditya, 2009).

Hasil atau nilai tambah dari usaha pembibitan sapi potong berupa pedet atau anak sapi yang unggul sangat diperlukan, agar pada usaha penggemukan bibit bakalan tersebut dapat memberikan hasil pertambahan bobot berat badan sapi yang tinggi. Usaha pembibitan sapi potong selama ini memang kurang memberikan keuntungan yang memadai. Besarnya modal yang dibutuhkan untuk usaha pembibitan juga menjadi penyebab lain rendahnya minat pengusaha untuk investasi di usaha pembibitan sapi potong. Hal tersebut tidak sebanding dengan usaha penggemukan yang memberikan keuntungan berlipat ganda (Bade, 2002).

Usaha penggemukan sapi yang dimaksud yaitu suatu cara pemeliharaan di kandang secara terus-menerus dalam waktu minimal 6 bulan. Tujuan pemeliharaan sapi dengan cara ini adalah untuk meningkatkan atau menghasilkan daging yang relatif lebih cepat. Usaha penggemukan sapi merupakan salah satu peluang usaha yang paling mudah untuk dilaksanakan, karena tidak harus memiliki modal besar dan tidak terlalu membutuhkan keahlian khusus. Sedangkan, di Indonesia akhir-akhir ini sudah banyak berkembang berbagai usaha penggemukan sapi yang dilakukan oleh para feedlotters atau peternak kecil. Bagi peternak kecil, yang kebanyakan petani di desa-desa, usaha penggemukan sapi merupakan alternatif yang bisa di lakukan untuk menambah pendapatan keluarga. Usaha penggemukan sapi potong dapat memberikan keuntungan finansial jauh lebih besar dalam waktu yang lebih pendek, sehingga usaha penggemukan lebih menarik bagi investor dibandingkan usaha pembibitan (Kardiyanto, 2001).
Sekjen Perhimpunan Peternak Sapi dan Kerbau Indonesia (PPSKI), mengatakan bahwa pada saat ini pengusaha tidak lagi tertarik berinvestasi di budidaya sapi (on farm). Penyebabnya adalah nilai tambah yang diperoleh sangat kecil dan harus menanggung risiko yang cukup besar. Berbeda dengan peternakan di Australia yang dikelola dalam skala besar, usaha budidaya sapi di Indonesia adalah usaha sampingan dengan skala kecil dan rumah tangga. Akibatnya, budidaya sapi di Indonesia tidak efisien dan nilai tambah yang diperoleh menjadi kecil. Usaha pembibitan sapi potong dengan skala usaha 2-5 ekor belum memberikan keuntungan, sedangkan untuk usaha penggemukan sapi pada skala 2-5 ekor sudah memberikan keuntungan bagi peternak (Hardjosubroto, 2004).

Salah satu hal yang perlu mendapatkan perhatian lebih dalam pengembangan usaha penggemukan sapi dan untuk menjaga eksistensi usaha penggemukan sapi, seperti yang ada di Kabupaten OKU Timur adalah bagaimana mengkondisikan para pengusaha penggemukan sapi yang ada untuk menggunakan faktor-faktor produksi yang ada dengan seefisien mungkin. Sedangkan, salah satu jenis sapi yang memiliki prospek untuk dikembangkan di Kabupaten OKU Timur adalah sapi brahman. Hal tersebut dikarenakan bakalan sapi brahman selain memiliki pangsa pasar yang tinggi, juga memiliki pertumbuhan yang cukup baik, sehingga akan menghasilkan output dan keuntungan yang optimal.

\section{B. Rumusan Masalah}

1. Berapa besar biaya produksi, penerimaan, dan pendapatan usaha penggemukan sapi brahman di Kabupaten OKU Timur.

2. Berapa besar nilai tambah usaha penggemukan sapi brahman di Kabupaten OKU Timur.

3. Bagaimana tingkat kelayakan usaha penggemukan sapi brahman di Kabupaten OKU Timur.

\section{Tujuan dan Kegunaan}

1. Untuk mengetahui biaya produksi, penerimaan, dan pendapatan usaha penggemukan sapi brahman di Kabupaten OKU Timur.

2. Untuk mengetahui nilai tambah usaha penggemukan sapi brahman di Kabupaten OKU Timur. 
3. Untuk mengetahui tingkat kelayakan usaha penggemukan sapi brahman di Kabupaten OKU Timur.

\section{Model Pendekatan}

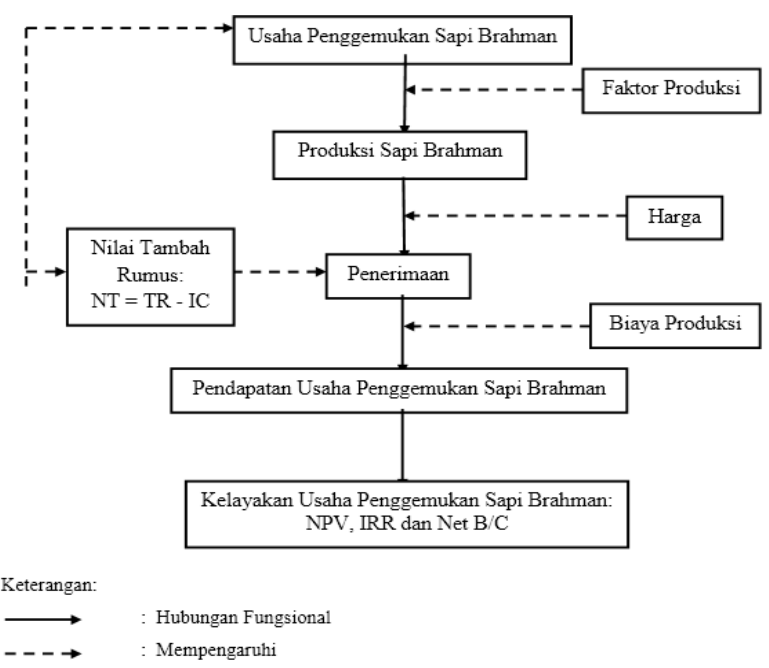

Gambar 1. Model pendekatan penelitian secara diagramatik.

\section{METODOLOGI PENELITIAN}

\section{A. Tempat dan Waktu}

Penelitian dilaksanakan di Kabupaten OKU Timur, dengan penentuan lokasi penelitian secara sengaja (purposive) dengan pertimbangan bahwa masih sedikit para pelaku usaha penggemukan sapi yang memilih untuk menggemukan sapi brahman, padahal usaha penggemukan sapi brahman di Kabupaten OKU Timur memiliki prospek yang cukup baik. Hal tersebut dikarenakan permintaan sapi brahman dari tahun ke tahun terus meningkat, selain itu proses penggemukan sapi brahman cukup mudah serta dalam waktu yang relatif tidak terlalu lama sudah diperoleh keuntungan. Penelitian ini telah dilaksanakan pada Bulan Maret 2015 sampai dengan Bulan Mei 2015 pada usaha penggemukan sapi brahman yang telah ada di Kabupaten OKU Timur.

\section{B. Metode Penelitian}

Metode yang digunakan dalam penelitian ini adalah metode survey yang terpusat pada usaha penggemukan sapi brahman di Kabupaten OKU Timur. Menurut Etta dan Sopiah (2010), metode survey merupakan metode penelitian mengenai status subjek penelitian, yang berkenaan dengan fase spesifik atau khas dari keseluruhan petani subjek penelitian baik berupa individu, kelompok maupun masyarakat terhadap topik atau isu-isu tertentu. Tujuan utama dari metode survey adalah untuk mengetahui gambaran umum karakteristik dari populasi dan untuk mengetahui variabel yang diteliti atau karakteristik sampel dari jumlah populasi yang diteliti.

\section{Metode Penarikan Contoh}

Metode penarikan contoh yang digunakan adalah metode sensus dengan menggunakan sample daerah pada lokasi penelitian di Kabupaten OKU Timur dan yang menjadi sample adalah pelaku usaha penggemukan sapi brahman yang ada di Kabupaten OKU Timur. Jumlah populasi pelaku usaha penggemukan sapi brahman adalah 9 dari 5 kecamatan yang terdiri dari 9 desa, dengan total jumlah sapi brahman yang digemukan adalah 20 ekor sapi. Jadi jumlah sample pelaku usaha penggemukan sapi brahman adalah 9 pelaku usaha dari 9 jumlah populasi, seperti dapat di lihat pada tabel berikut:

Tabel 1. Jumlah Responden Usaha Penggemukan Sapi Brahman yang ada di Kabupaten OKU Timur.

\begin{tabular}{|c|c|c|c|c|c|c|}
\hline \multirow{2}{*}{ No } & \multirow{2}{*}{ Kecamatan } & \multirow{2}{*}{ Desa } & \multicolumn{2}{|c|}{ Jumlah Pelaku Usaha } & \multicolumn{2}{|c|}{ Jumlah Sapi Brahman } \\
\hline & & & Populasi & Sample & Populasi & Sample \\
\hline 1 & Belitang & Triyoso & 1 & 1 & 3 & 3 \\
\hline \multirow[t]{5}{*}{2} & Buay Madang Timur & Donoharjo & 1 & 1 & 1 & 1 \\
\hline & & Bangun Harjo & 1 & 1 & 3 & 3 \\
\hline & & Srimulyo & 1 & 1 & 2 & 2 \\
\hline & & Sumberharjo & 1 & 1 & 3 & 3 \\
\hline & & Karang Tengah & 1 & 1 & 4 & 4 \\
\hline 3 & Belitang Madang Raya & Jati Mulyo & 1 & 1 & 1 & 1 \\
\hline 4 & Semendawai Suku III & Taraman & 1 & 1 & 2 & 2 \\
\hline \multirow[t]{2}{*}{5} & Madang Suku I & Mendayun & 1 & 1 & 1 & 1 \\
\hline & Jumlah & 9 Desa & 9 & 9 & 20 & 20 \\
\hline
\end{tabular}

Sumber: Data Olahan Primer Tahun 2015.

\section{Metode Pengolahan Data}

Data yang diperoleh dari penelitian dikelompokan kemudian diolah secara tabulasi, yaitu menghitung besarnya biaya produksi, penerimaan, dan pendapatan usaha penggemukan sapi brahman, rumus yang digunakan adalah sebagai berikut:

1) Untuk mengetahui biaya produksi, penerimaan, dan pendapatan:

a)Menurut Suratiyah (2006), untuk mengetahui biaya produksi maka digunakan rumus:

$\mathrm{TC}=\mathrm{FC}+\mathrm{VC}$

Keterangan:

$\mathrm{TC}=$ Total Cost $($ Total Biaya $)$

$\mathrm{FC}=$ Fixed Cost (Biaya Tetap)

$\mathrm{VC}=$ Variabel Cost $($ Biaya Tidak Tetap $)$ 
b) Menurut Suratiyah (2006), untuk mengetahui besarnya penerimaan maka digunakan rumus:

$\mathrm{R}=\mathrm{P} \times \mathrm{Y}$

Keterangan:

$\mathrm{R}=$ Revenue (Penerimaan)

$\mathrm{P}=$ Price $($ Harga $)$

$\mathrm{Y}=$ Yield (Produksi)

c)Menurut Suratiyah (2006), untuk mengetahui besarnya pendapatan maka digunakan rumus: $\mathrm{I}=\mathrm{R}-\mathrm{TC}$

Keterangan:

$\mathrm{I}=$ Income (Pendapatan)

$\mathrm{R}=$ Revenue (Penerimaan)

$\mathrm{TC}=$ Total Cost (Total Biaya)

2) Untuk mengetahui nilai tambah:

Menurut Yudi, B., et.,all (2010), untuk mengetahui nilai tambah digunakan rumus:

$\mathrm{NT}=\mathrm{TR}-\mathrm{IC}$

Keterangan :

NT= Nilai Tambah

$\mathrm{TR}=$ Total Revenue $($ Total Penerimaan $)$

IC $=$ Intermediate Cost (Biaya Antara)

3) Untuk mengetahui kelayakan usaha:

a. Menurut Ibrahim (2009), untuk mengetahui

Net Present Value maka bisa menggunakan rumus:

$\mathrm{NPV}=\sum_{\mathrm{i}=1}^{\mathrm{n}} \mathrm{NB}_{\mathrm{i}}$

Keterangan:

$\mathrm{NB}=$ Net Benefit $=$ Benefit - Cost

$\mathrm{C}=$ Biaya Investasi + Biaya Operasi

$\overline{\mathrm{B}}=$ Benefit yang telah di-discount

$\overline{\mathrm{C}}=$ Cost yang telah di-discount

i = Discount factor (faktor bunga)

$\mathrm{n}=$ Tahun (Waktu)

b.Menurut Ibrahim (2009), untuk mengetahui tingkat pengembalian modal usaha maka digunakan rumus Internal Rate of Return yaitu:

$\mathrm{IRR}=\mathrm{i}_{1}+\frac{\mathrm{NPV}_{1}}{\left(\mathrm{NPV}_{1}-\mathrm{NPV}_{2}\right)} \times \mathrm{i}_{2}-\mathrm{i}_{1}$

Keterangan:

$\mathrm{i}_{1}=$ Tingkat discount rate yang menghasilkan $\mathrm{NPV}_{1}$

$\mathrm{i}_{2}=$ Tingkat discount rate yang menghasilkan $\mathrm{NPV}_{2}$

c. Menurut Ibrahim (2009), untuk menganalisis efisiensi atau kelayakan menggunakan rumus Net Benefit Cost Ratio (Net B/C) yaitu:

Net $B / C$ Ratio $=\frac{\sum_{i=n}^{\text {un }} \mathrm{N}_{i}(+]}{\sum_{i=n}^{n} \mathrm{NB}_{i}(-]}$

Dengan Kriteria:
- Net B/C Ratio = 1 : Usaha tersebut balik modal persis sama dengan biaya yang dikeluarkan (Break Event Point)

- Net B/C Ratio < 1 : Usaha tersebut ditolak karena tidak menguntungkan (Non Feasible)

- Net B/C Ratio > 1 : Usaha tersebut boleh dilaksanakan karena menguntungkan (Feasible).

\section{HASIL DAN PEMBAHASAN}

\section{Analisis Usaha Prospek Nilai Tambah Usaha Penggemukan Sapi Brahman di Kabupaten OKU Timur.}

\section{Total Biaya Produksi (Total Cost)}

Menurut Mulyadi (2007), biaya produksi adalah semua pengeluaran yang dilakukan oleh perusahaan untuk faktor-faktor produksi, sehingga memperoleh output. Sedangkan, menurut Kusnadi (2006), biaya produksi adalah semua pengorbanan yang perlu dilakukan oleh produsen/perusahaan untuk suatu proses produksi, yang dinyatakan dengan satuan uang menurut harga pasar yang berlaku, baik yang sudah terjadi maupun yang akan terjadi. Korbanan atau biaya ini berada posisi yang harus seefesien mungkin agar mempunyai keuntungan yang optimal.

Biaya tetap adalah biaya yang tidak habis dalam satu kali proses produksi, yaitu biaya sewa lahan dan total biaya penyusutan alat. Sedangkan biaya variabel adalah biaya yang habis dalam satu kali proses produksi, diantaranya biaya sarana produksi dan tenaga kerja, dan biaya sarana produksi dapat berupa bakalan sapi brahman, pakan, dan vitamin serta obat.

Tabel 2. Rincian Rata-rata Biaya Produksi Usaha Penggemukan Sapi Brahaman Perproses Produksi.

\begin{tabular}{|c|c|c|}
\hline No. & Uraian & Usaha Penggemukan Sapi Brahman (Rp/PP) \\
\hline 1. & $\begin{array}{l}\text { Biaya Tetap } \\
\text { Sewa Tempat Usaha } \\
\text { Biava Penvusutan Alat (BPA) }\end{array}$ & $\begin{array}{l}3.588 .335=- \\
3.055 .556=- \\
532.779-\end{array}$ \\
\hline 2. & $\begin{array}{l}\text { Biaya Variabel } \\
\text { Biaya Sarana Produksi } \\
\text { Biaya Tenaga Kerja }\end{array}$ & $\begin{array}{r}75.849 .889,- \\
71.183 .222,- \\
4.666 .667,-\end{array}$ \\
\hline & Total Biaya $(1+2)$ & $79.438 .224,-$ \\
\hline
\end{tabular}

Sumber: Data Primer (Diolah), 2015.

Berdasarkan tabel di atas diketahui rata-rata besarnya biaya tetap yang dikeluarkan pelaku usaha penggemukan sapi brahman adalah Rp. 3.588.335,-/PP yang digunakan untuk sewa tempat usaha Rp. 3.055.556,-/PP dan biaya penyusutan alat Rp. 532.779,-/PP. Selain biaya 
tetap dikeluarakan juga biaya variabel sebesar $\mathrm{Rp}$. 75.849889,-/PP diantaranya untuk biaya sarana produksi sebesar Rp. 71.183.222,-/PP serta untuk biaya tenaga kerja mulai sebesar Rp. 4.666.667,/PP. Sehingga total dari keseluruhan biaya yang dikeluarkan selama satu kali poses produksi adalah jumlah dari biaya tetap ditambah dengan jumlah biaya variabel maka total biaya produksi adalah Rp. 79.438.224,-/PP.

\section{Produksi, Harga, Penerimaan, dan} Pendapatan Perproses Produksi.

Hasil penelitian di lapangan untuk produksi, penerimaan dan pendapatan usaha penggemukan sapi brahman dapat dilihat pada tabel berikut ini:

Tabel 3. Rincian Rata-rata Produksi, Penerimaan, dan Pendapatan Usaha Penggemukan Sapi Brahman Perproses Produksi.

\begin{tabular}{|c|c|c|}
\hline No & Uraian & Usaha Penggemukan Sapi Brahman (Rp/PP) \\
\hline 1. & Produksi & 2 ekor \\
\hline 2. & Harga & Rp. $\quad 56.222 .222$,-ekor $P P$ \\
\hline 3. & Total Biaya Produksi (Rp/PP) & Rp. $\quad 79.438 .224,-$ PP \\
\hline 4. & Penerimaan ( $\mathrm{Rp} / \mathrm{PP})$ & Rp. 123.333.333,-/PP \\
\hline 5 . & Pendapatan (Rp/PP) & Rp. $\quad 43.895 .109,-$ PP \\
\hline 6. & Pendapatan (Rp/Bulan) & Rp. $\quad 7.315 .852,-$ Bulan \\
\hline
\end{tabular}

Sumber: Data Primer (Diolah), 2015.

Setiap produksi sapi brahman rata-rata 2 ekor/PP dengan harga rata-rata Rp. 56.222.222,lekor. Harga akan mempengaruhi besarnya penerimaan yang diterima oleh pelaku usaha penggemukan sapi brahman. Produksi sapi brahman selama ini dibeli langsung oleh pembeli yang diundang oleh pelaku usaha langsung untuk datang ke lokasi. Hal tersebut dilakukan karena untuk menekan biaya produksi agar bisa sekecil mungkin.

Penerimaan adalah jumlah penghasilan produksi dalam satuan fisik dikalikan dengan harga jual, yang didefinisikan sebagai nilai uang yang diterima. Tujuan akhir dari pengelolaan usahatani adalah perolehan besarnya pendapatan tunai atau proporsi penerimaan yang dapat digunakan sebagai perbandingan keberhasilan antar pelaku usaha (Saragih, 2001). Penerimaan yang diterima oleh pelaku usaha penggemukan sapi brahman rata-rata sebesar Rp. 123.333.333,-/PP, sedangkan biaya produksi yang dikeluarkan adalah Rp. 79.438.224,-./PP. Besarnya biaya produksi yang dikeluarkan akan mempengaruhi pendapatan yang diterima oleh pelaku usaha. Besarnya pendapatan yang diperoleh adalah $\mathrm{Rp}$. 43.895.109,-/PP (Rp. 7.315.852,-/bulan).

\section{Analisis Nilai Tambah Usaha Penggemukan Sapi Brahman Perproses Produksi.}

Besarnya nilai tambah pada usaha penggemukan sapi brahaman dapat dilihat pada tabel berikut.
Tabel 4. Rata-rata Nilai Tambah Usaha Penggemukan Sapi Brahman Perproses Produksi.

\begin{tabular}{|c|c|}
\hline No. & Usaha Pengegemukan Sapi Brahman (RppP) \\
\hline$\Sigma$ & Rp. 59.305.278,-ekor (Rp. 118.610.555;-PP atau Rp. 19.768.426,-Bulan) \\
\hline
\end{tabular}

Sumber: Data Primer (Diolah), 2015.

Analisis nilai tambah usaha penggemukan sapi brahman dilakukan untuk mengetahui besarnya nilai yang ditambahkan pada bakalan sapi brahman yang setelah digemukan berat badan sapi brahman dapat bertambah. Analisis nilai tambah usaha penggemukan sapi brahman dengan produk akhir yang diterima adalah nilai yang diberikan atau dijual dari pelaku usaha kepada konsumen. Semakin besar nilai tambah yang diperoleh maka semakin besar juga keuntungan yang diperoleh oleh pengusaha dan juga sebaliknya. Nilai tambah pada usaha penggemukan sapi brahman rata-rata adalah $\mathrm{Rp}$. 59.305.278,-/ekor (Rp. 118.610.555,-/PP atau Rp. 19.768.426,-/Bulan) diperoleh dari selisih nilai akhir dengan biaya pembelian bakalan sapi brahman.

\section{Analisis Kelayakan Usaha Penggemukan Sapi Brahman Perproses Produksi}

Analisis nilai kelayakan usaha penggemukan sapi brahman pada tahun-tahun yang akan mendatang, dihitung dengan menggunakan rumus NPV, IRR dan Net B/C, sehingga diketahui perkiraan pendapatan yang akan diterima pada tahun-tahun yang akan mendatang. Pada analisis NPV, IRR dan Net B/C, usaha penggemukan sapi brahman dihitung dari sejak persiapan usaha. Menurut Ibrahm (2009), analisis Net Present Value (NPV) adalah kriteria yang banyak digunakan dalam mengukur apakah suatu usaha/proyek feasible atau tidak.

Perhitungan NPV merupakan net benefit yang telah didiskon dengan menggunakan Social Opportunity Cost of Capital (SOCC) sebagai discount factor. Apabila hasil perhitungan NPV lebih besar dari 0 (nol), maka usaha/proyek tersebut dikatakan feasible (go) untuk dilaksanakan, dan jika lebih kecil dari 0 (nol) maka tidak layak untuk dilaksanakan. Selain itu, apabila NPV sama dengan 0 (nol) maka berarti usaha/proyek tersebut berada dalam keadaan Break Even Point (BEP) dimana TR = TC dalam bentuk present value.

Menurut Ibrahim(2009), ukuran ke dua dari perhitungan kriteria investasi setelah NPV adalah IRR. IRR atau Internal Rate of Return (IRR) merupakan suatu tingkat discount rate yang menghasilkan net present value sama dengan 0 
(nol). Sehingga, dengan demikian apabila hasil perhitungan IRR lebih besar dari Social Opportunity Cost of Capital (SOCC) maka usaha/proyek tersebut dikatakan feasible, jika sama dengan SOCC berarti pulang pokok dan jika di bawah SOCC maka usaha/proyek tersebut dikatakan tidak feasible. Cara yang dilakukan untuk menentukan besarnya nilai IRR adalah harus dihitung terlebih dahulu nilai $\mathrm{NPV}_{1}$ dan nilai $\mathrm{NPV}_{2}$ dengan cara coba-coba. Apabila nilai $\mathrm{NPV}_{1}$ telah menunjukan angka positif maka discount factor yang ke dua harus lebih besar dari SOCC, dan sebaliknya apabila $\mathrm{NPV}_{1}$ menunjukan angka negatif maka discount factor yang ke dua harus berada di bawah SOCC atau discount factor.

Net Benefit Cost Ratio (Net B/C) menurut Ibrahim (2009) merupakan perbandingan antara net benefit yang telah di discount positif (+) dengan benefit yang telah di discount negatif (-). Jika nilai Net B/C lebih besar dari 1 (satu) berarti gagasan usaha/proyek tersebut layak untuk dikerjakan, dan jika lebih kecil dari 1 (satu) berarti tidak layak untuk dikerjakan. Sedangkan, untuk Net B/C sama dengan 1 (satu) berarti cash in flows sama dengan cash out flows, dalam present value disebut dengan Break Event Point (BEP) yaitu total cost sama dengan total revenue. Oleh sebab itu, apabila hasil perhitungan telah menunjukan feasible (layak), maka pelaksanaannya akan jarang mengalami kegagalan. Kegagalan hanya terjadi karena faktor-faktor uncrontrolable seperti banjir, gempa bumi, perubahan peraturan pemerintah, disamping data yang digunakan tidak relevan.

Tabel 5. Nilai NPV, IRR dan Net B/C Ratio Usaha Penggemukan Sapi Brahman Perproses Produksi.

\begin{tabular}{lcrr}
\multicolumn{1}{l}{ NPV } & \multicolumn{2}{l}{ NRR } & Net B/C \\
\hline $85,691,855$ & $32,16 \%$ & & $(1.89)$ \\
\hline
\end{tabular}

Sumber: Data Primer (Diolah), 2015.

Berdasarkan tabel 4 dan 5 di atas maka dapat diketahui bahwa usaha penggemukan sapi brahman memiliki nilai NPV pada suku bunga bank $18 \%$ sebesar Rp. 85.691.855,- yang artinya pada suku bunga bank $18 \%$ investasi pada usaha penggemukan sapi brahman lebih menguntungkan dibandingkan dengan menginvestasikan uang di bank. Nilai IRR diperoleh sebesar 32,16 \% yang artinya suku bunga yang diterima lebih besar dari suku bunga bank yang berlaku yaitu $18 \%$ sehingga usaha penggemukan sapi brahman semakin layak untuk dikembangkan. Sedangkan, untuk mengetahui nilai perbandingan $\mathrm{PV}$ positif dan PV negatif diperoleh Net B/C sebesar 1,89 yang berarti usaha feasible (usaha boleh dilaksanakan karena menguntungkan).

\section{IV.KESIMPULAN DAN SARAN A. Kesimpulan}

Berdasarnya hasil penelitian dan analisis yang telah dilakukan, maka dapat ditarik kesimpulan sebagai berikut:

1. Rata-rata dikeluarkan biaya produksi untuk kegiatan usaha penggemukan sapi brahman sebesar Rp. 79.438.224,-/PP, dengan biaya tetap sebesar Rp. 3.588.335,-/PP, dan biaya variabel sebesar Rp. 75.849.889,-/PP. Penerimaan diperoleh Rp. 123.333.333,-/PP maka diperoleh pendapatan sebesar Rp. 43.895.109,-/PP (Rp. 7.315.852,-/Bulan).

2. Nilai tambah usaha penggemukan sapi brahman di Kabupaten OKU Timur rata-rata adalah sebesar Rp. 59.305.278,-/ekor (Rp. 118.610.555,-/PP atau Rp. 19.768.426,/Bulan).

3. Usaha penggemukan sapi brahman yang ada di Kabupaten OKU Timur dapat dikatakan menguntungkan dan layak untuk dilakukan. Hal tersebut dikarenakan pada usaha penggemukan sapi brahman diperoleh nilai NPV pada suku bunga bank $18 \%$ (Rp. 85.691.855,-) dengan nilai Net B/C sebesar 1,89 dan nilai IRR $32,16 \%$ yang berati feasible atau usaha dapat dilakukan karena menguntungkan.Sehingga,usaha penggemukan sapi brahman di Kabupaten OKU Timur memiliki prospek yang baik untuk dikembangkan.

\section{B. Saran}

Saran yang dapat berikan berdasarkan hasil penelitian yang telah dilakukan pada usaha penggemukan sapi brahamn yang ada di Kabupaten OKU Timur adalah sebagai berikut:

1.Pelaku usaha penggemukan sapi brahman sebaiknya menambah jumlah bakalan sapi brahman, sehingga pendapatan yang diperoleh pelaku usaha akan semakin besar.

2.Pelaku usaha penggemukan sapi brahman sebaiknya memilih bakalan sapi brahman yang berkualitas.

3.Para pelaku usaha penggemukan sapi brahman sebaiknya bekerja sama dengan pemerintah mulai dari pengadaan bakalan sampai ke tingkat pemasaran. 


\section{DAFTAR PUSTAKA}

Aditya. 2009. Tekhnik Penggemukan Sapi Brahman. Graha Ilmu Yogyakarta.

Arsyad, L. 2003. Ekonomi Manajerial, Edisi Kelima. Balai Pustaka. Yogyakarta.

Bade, D.H. 2002. Ilmu Peternakan, Edisi ke empat. Terjemahan B. Srigandono. UGM Press. Yogyakarta.

Etta, M. S. dan Sopiah. 2010. Metodelogi Penelitian. ANDI. Yogyakarta.

Faizul. 2009. Ekonomi Makro. Graha Ilmu. Yogyakarta.

Gunawan, et all. 2008. Petunjuk Pemeliharaan Sapi Brahman. BPTU Sapi Dwiguna dan Ayam Sembawa. Direktorat Jenderal Peternakan Departemen Pertanian.

Hardjosubroto, W. 2004. Buku Pintar Peternakan. PT. Gramedia Widiasarana Indonesia. Jakarta.

Hernanto, F. 1997. Ilmu Usahatani. Penebar Swadaya. Jakarta.

Ibrahim, Y. 2009. Study Kelayakan Bisnis. Rineka. Jakarta.

Juanda. 2004. Paradigma Baru Pembangunan Pertanian. Raja Grafindo Persada. Jakarta.

Kardiyanto, E. 2011. Budidaya Ternak Sapi Potong. Rineka. Jakarta.

Kartasapoetra. 2003. Dasar-dasar Ilmu Usaha. LP3ES. Jakarta.

Kusnadi. 2006. Studi Kelayakan Bisnis. Universitas Bramawijaya. Malang.

Kuswadi. 2007. Analisis Keekonomian Proyek. Andi Offset. Yogyakarta.
Manullang. 2003. Analisis Harga. LP3ES. Jakarta.

Mulyadi. 2009. Akuntansi Biaya, Edisi Kelima. Graha Ilmu. Yogyakarta.

Rivai. 2009. Analisis Kelayakan Usaha Penggemukan Sapi Potong (fattening) pada PT. Zagrotech Dafa International (ZDI) Kecamatan Cimpea Kabupaten Bogor. Fakultas Ekonomi dan Manajemen. Institut Pertanian Bogor.

Samoelson dan Naredhous. 2000. Pemasaran Produksi Pertanian dan Pengkajian Pemasaran Komoditas. IPB. Bogor.

Saragih, B. 2001. Suara dari Bogor Membangun Sistem Agribisnis. Yayasan USESE bekerjasama dengan SUCOFINDO. Bogor.

Sjarkowi, F dan Marwan, S. 2004. Manajemen Agribisnis. CV. Baldad Grafitti Press. Palembang.

Sjarkowi, F. 2010. Manajemen Pembangunan Agribisnis. CV. Baldad Grafitti Press. Palembang.

Soekartawi. 2002. Prinsip Dasar Komunikasi Pertanian. UI Press. Jakarta.

Suratiyah, K. 2006. Faktor-faktor Produksi. PT Penebar Swadaya. Jakarta.

Teken dan Asnawi. 2005. Teori Ekonomi Makro. Erlangga. Jakarta.

Yudi, B.D. dan Rahayu, R. 2010. Jumlah Sistem Agribisnis Terintegrasi Hulu-Hilir. Muara Indah. Bandung.

Zulkarnain. 2005. Studi Kelayakan Usaha. Prehalindo. Jakarta. 